\title{
Influence of Moisture Stress on Root Traits and Yield Components of Mungbean Genotypes
}

\author{
Y. Yohan ${ }^{1}$ *. P. Sudhakar ${ }^{1}$, V. Umamahesh ${ }^{1}$, D. Mohan $\operatorname{Reddy}^{2}$ and V. Sumathi ${ }^{3}$ \\ ${ }^{1}$ Department of Crop Physiology, ${ }^{2}$ Department of Genetics and Plant Breeding, \\ ${ }^{3}$ Department of Agronomy, S.V. Agricultural College, Tirupati, A.P., India \\ *Corresponding author
}

\section{A B S T R A C T}

\section{Keywords}

Mungbean

Genotypes,

Moisture stress,

Root traits

Article Info

Accepted:

20 November 2018

Available Online:

10 December 2018
A field experiment was conducted at the experimental field twelve Mungbean (Vigna radiata $\mathrm{L}$.) genotypes under water stress condition. A wide diversity among the genotypes in their root characters including yield was recorded. Genotypes varied from genotypes TBG-104, KU-12-13 root length was increased during moisture stress condition in both the years. But genotypes showed lower amount of root dry weight, pod dry weight along with number pods per plant and number pods per cluster in irrigated control as well as moisture condition. TBG-104, KU-12-13, KU-12-37, LBG-645recorded significantly more root length, root and pod dry matter, pods per plant and pods per cluster under both irrigated as well as stress conditions, which denotes the ability of these genotypes in sustaining the higher root length and absorb the water from deeper layers of soils. Whereas NDU-12-300 and LBG- 680 recorded lowest total dry matter during rabi 2015-16 and rabi 2016-17.

\section{Introduction}

Irrigated agriculture is essential to global food production, utilizing only $20 \%$ of cultivated land to provide $40 \%$ of the world's food supply (Garces-Restrepo et al., 2007). However, climate change, increasing worldwide shortages of water, frequent droughts, and global warming (Hirich et al., 2016) are threatening the reliability of irrigation water supplies.

While the human population and demands for freshwater resources are increasing, drought and regular water scarcity can put global food security at risk (Lei et al., 2016), by severely disrupting agricultural production. The challenge is to meet rising productivity demands by improving methods of crop management (Behmann et al., 2014), and this requires a deeper understanding of plant response to abiotic stress.

Among the various pulses, blackgram or urdbean (Vignamungo [L.] Hepper) is an important grain legume with easily digestible protein. It belongs to the family fabaceace with $2 n=22$. Blackgram grain contains about 25 per cent protein, 56 per cent carbohydrate, 2 per cent fat, 4 per cent minerals and 0.4 per 
cent vitamins. Vigna mungo (L.) Hepper, commonly known as blackgram, contributes $20 \%$ to overall world pulse production (Saravanakumar et al., 2007). In India, blackgram is cultivated in an area of 761.3 thousands of hectares, with a production of 678.6 thousand tonnes and with the productivity of $891.0 \mathrm{~kg} \mathrm{ha}^{-1}$

However, production of blackgram is adversely affected by various environmental stress factors, especially drought that reduce yield (Pandey et al., 2014). Reduced root length due to water stress. It impairs root cell development, nutrient uptake and affects photosynthesis; hence, affect root elongation (Dhole and Reddy, 2010). Deep and dense root system display better drought tolerance by extracting water from deeper layers (Parameshwarappa et al., 2012). Plants subjected to drought at yearly reproductive stage produced lowest number of podsper plant and yield (Baroowa and Gogoi, 2014).

\section{Materials and Methods}

The experiment was laid out in a split plot design with two main treatments, twelve sub treatments and replicated thrice. Main Treatments: 2: i) Irrigated (control) ii) Impose moisture stress at 60-80 DAS, Sub Treatments (12 Genotypes) KU -12-55, LBG-623, LBG680, NDU-12-300, LBG-685, KU-12-14, LBG-645, KU-12-37, TBG-104, KU-12-33, LBG-752 and LBG-20. Following parameters are recorded at 45, 52 and 60 DAS and after harvest in both rabi 2015-16 and rabi 201617.

\section{Water mining root traits}

\section{Root length (cm)}

Root length was measured using a standard scale from the ground level to the tip of the root.

\section{Root dry matter (g plant $\left.{ }^{-1}\right)$}

The dry weights of oven dried roots and pods were recorded and expressed as g plant ${ }^{-1}$

\section{Post harvest parameter}

The crop at maturity was harvested from one meter square area (net plot area $6 \mathrm{~m}^{2}$ ) for recording final yield data.

\section{Number pods per plant}

The total number of pods from plants harvested in one $\mathrm{m}^{2}$ were counted and averaged to get number of pods plant ${ }^{-1}$

\section{Number cluster per plant}

The total number of clusters from plants harvested in one $\mathrm{m}^{2}$ were counted and averaged to get number of cluster plant ${ }^{-1}$

\section{Number pods per cluster}

The total number of pods from cluster harvested in one $\mathrm{m}^{2}$ were counted and averaged to get number of pods cluster ${ }^{-1}$

\section{Results and Discussion}

Significant differences were observed among the genotypes, treatments and their interactions in both the years. Due to imposition of moisture stress at pod formation stage i.e. from 40-60 DAS the root length increased whereas root dry weight was decreased significantly. The extent of increase was 16.3 and 14.7 per cent of root length and 55.9 and 52.2 per cent of root weight at 60 DAS when compared to irrigated control of rabi 2016 and rabi 2017 respectively (Fig. 1a and 1b). Similar results were in blackgram (Dahanayake Nilanthi et al., 2014). 
The genotypes TBG-104, KU-12-13, KU-1237 recorded higher root length but lower root weight compared to other genotypes both under irrigated and moisture stress conditions (Plate 1). Higher root length helps in with stand stress through better availability of water from soil deeper layers were also reported in cowpea (Onuh and Donald (2009) and groundnut (Venkateswarlu, 2005). More root length helps the plants to withstand stress through more availability of water this leads tolerant to water deficit conditions and increase the photosynthetic rate, more dry matter production and higher productivity as it was noticed in the genotypes TBG-104 and KU-12-13 (Fig. 2a and 2b).

Pod dry weight showed significant differences among treatments, genotypes and their interactions effects during both the years. The extent of decrease was 44.8 and 44.18 percent at 60 DAS and 43.4 and 43.2 percent at 75 DAS in both the years (Table 1) compared to respective irrigated treatments. These results further established pod dry weight is sensitive to moisture stress. Similar results were reported by Uddin et al., 2013. TBG-104 recorded highest pod dry weight under irrigated (7.88 and 7.73 gplant $^{-1}$ ) as well as moisture stress (6.96 and6.86 gplant $\left.^{-1}\right)$ conditions followed by KU-12-13 and LBG680.These results further established pod.

Pods per plant were significantly reduced due to imposition of stress at pod formation to pod filling stages, denoting the fact that number of pods is affected irrespective of moisture stress. However reduction in number of pods per plant was 33.2 and 46.2 per cent during rabi 2016 and rabi 2017. Similar significance results were discovered in chickpea (Lutfor Rahman et al., 2000 and Tejpal Singh et al., 2003).

The genotypes tested were also significantly varied for number of pods per plant among the genotypes, TBG-104 recorded highest mean number of pods plant (63.67 \& 55.99) followed by KU-12-13. KU-12-37, LBG-680, and LBG-645 recorded moderate number of pods per plant, where as NDU-12-300 recorded lowest number of pods per plant under irrigated and moisture stress treatments during both the years (Table $2 \mathrm{a}$ and $2 \mathrm{~b}$ ). Similar results were observed in blackgram (Dahanayake Nilanthi et al., 2014 and Anitha et al., 2015; Pandiyan et al., 2017).

Imposition of moisture stress at pod formation to pod filling significantly reduced number of clusters per plant compared to irrigated control. The extent of decrease was 28.2 and 30.0 compared to irrigated control.

Among the genotypes, irrespective of irrigation and moisture stress treatments, TBG-104, KU-12-13 and KU-12-55 recorded highest mean number of clusters per plant compared to among genotypes. LBG-680, LBG-645 and LBG-623 recorded moderate number of pods per cluster, where as NDU12-300 recorded lowest number of clusters per plant during rabi 2016 and rabi 2017 (Table $2 \mathrm{a}$ and $2 \mathrm{~b}$ ).

Biradar et al., (2007) reported that moisture stress affects yield and yield components and significant reduction was recorded for the yield and yield components. The reduction was more pronounced for number of pods cluster $^{-1}$ and less for number of seeds pod ${ }^{-1}$.

Significant differences were observed between moisture stress treatments, genotypes however their interactions were non-significant during both the years of testing. Pods per cluster were significantly reduced due to imposition of stress at pod formation to pod filling stages, denoting the fact that number of pods per cluster is less affected irrespective of moisture stress. 
Table.1 Evaluation of blackgram genotypes for pod dry weight $(\mathrm{g})$ under imposed moisture stress condition during rabi 2015-16and 2016-17

\begin{tabular}{|c|c|c|c|c|c|c|c|c|c|c|c|c|}
\hline \multirow[b]{3}{*}{ Genotypes } & \multicolumn{6}{|c|}{ 2015-16 } & \multicolumn{6}{|c|}{$2016-17$} \\
\hline & \multicolumn{3}{|c|}{60 DAS } & \multicolumn{3}{|c|}{ At harvest } & \multicolumn{3}{|c|}{60 DAS } & \multicolumn{3}{|c|}{ At harvest } \\
\hline & $\mathbf{M}_{0}$ & $\mathbf{M}_{1}$ & Mean & $\mathbf{M}_{\mathbf{0}}$ & $\mathbf{M}_{1}$ & Mean & $\mathbf{M}_{0}$ & $\mathbf{M}_{1}$ & Mean & $\mathbf{M}_{\mathbf{0}}$ & $\mathbf{M}_{1}$ & Mean \\
\hline KU-12-55 & 4.30 & 1.24 & 2.77 & 5.80 & 3.13 & 4.47 & 4.21 & 1.18 & 2.70 & 5.40 & 3.07 & 4.24 \\
\hline LBG-623 & 2.73 & 1.61 & 2.17 & 6.32 & 2.75 & 4.54 & 2.65 & 1.52 & 2.09 & 6.18 & 2.54 & 4.36 \\
\hline LBG-680 & 6.77 & 2.67 & 4.72 & 7.89 & 3.63 & 5.76 & 6.59 & 2.64 & 4.62 & 7.71 & 3.58 & 5.65 \\
\hline NDU-12-300 & 5.19 & 2.19 & 3.69 & 8.17 & 3.04 & 5.61 & 5.01 & 2.06 & 3.54 & 8.04 & 3.24 & 5.64 \\
\hline LBG-685 & 2.89 & 1.91 & 2.40 & 3.26 & 2.14 & 2.70 & 2.81 & 1.91 & 2.36 & 3.12 & 4.24 & 2.55 \\
\hline KU-12-14 & 3.97 & 2.56 & 3.26 & 5.04 & 3.00 & 4.02 & 3.99 & 2.42 & 3.21 & 4.91 & 4.36 & 3.88 \\
\hline LBG-645 & 4.06 & 3.02 & 3.54 & 6.50 & 3.60 & 5.05 & 3.84 & 2.91 & 3.38 & 6.39 & 3.49 & 4.94 \\
\hline KU-12-37 & 3.76 & 2.00 & 2.88 & 4.60 & 3.13 & 3.87 & 3.66 & 2.64 & 3.15 & 4.18 & 2.97 & 3.58 \\
\hline TBG-104 & 6.87 & 5.42 & 6.14 & 7.88 & 6.96 & 7.42 & 6.67 & 5.30 & 5.99 & 7.73 & 6.86 & 7.30 \\
\hline KU-12-13 & 4.91 & 3.56 & 4.24 & 6.51 & 5.15 & 5.83 & 4.83 & 3.48 & 4.16 & 6.29 & 5.08 & 5.69 \\
\hline LBG-752 & 3.17 & 1.11 & 2.14 & 4.14 & 1.68 & 2.91 & 3.04 & 0.99 & 2.02 & 3.95 & 1.51 & 2.73 \\
\hline LBG-20 & 3.32 & 1.34 & 2.33 & 4.89 & 1.96 & 3.43 & 3.22 & 1.16 & 2.19 & 4.81 & 1.85 & 3.33 \\
\hline \multirow[t]{2}{*}{ Mean } & 4.33 & 2.39 & & 5.92 & 3.35 & & 4.21 & 2.35 & & 5.73 & 3.25 & \\
\hline & $\mathbf{T}$ & G & $\mathbf{T} \times \mathbf{G}$ & $\mathbf{T}$ & G & $\mathbf{T} \times \mathbf{G}$ & $\mathbf{T}$ & G & $\mathbf{T} \times \mathbf{G}$ & $\mathbf{T}$ & $\mathbf{G}$ & $\mathbf{T} \times \mathbf{G}$ \\
\hline SE $m \pm$ & 0.034 & 0.17 & 0.11 & 0.04 & 0.23 & 0.16 & 0.03 & 0.16 & 0.12 & 0.04 & 0.22 & 0.16 \\
\hline $\mathrm{CD}(\mathrm{P}=0.05)$ & 0.21 & 0.48 & 0.70 & 0.29 & 0.66 & 0.96 & 0.21 & 0.47 & 0.69 & 0.29 & 0.64 & 0.93 \\
\hline
\end{tabular}

$\mathrm{M}_{0}$ : Irrigated (control), $\mathrm{M}_{1}$ : Moisture stress 
Table.2a Evaluation of blackgram genotypes for yield components under imposed moisture stress condition during rabi 2015-16

\begin{tabular}{|c|c|c|c|c|c|c|c|c|c|}
\hline & \multicolumn{3}{|c|}{ Number. of Pods per plant } & \multicolumn{3}{|c|}{ Number of clusters per plant } & \multicolumn{3}{|c|}{ Number of pods per cluster } \\
\hline Genotype & $\mathbf{M}_{0}$ & $\mathbf{M}_{1}$ & Mean & $\mathbf{M}_{0}$ & $\mathbf{M}_{1}$ & Mean & $\mathbf{M}_{0}$ & $\mathbf{M}_{1}$ & Mean \\
\hline KU-12-55 & 30.85 & 23.72 & 27.28 & 11.11 & 9.22 & 10.16 & 2.78 & 2.57 & 2.68 \\
\hline LBG-623 & 29.49 & 16.81 & 23.15 & 10.22 & 7.22 & 8.72 & 2.89 & 2.33 & 2.61 \\
\hline LBG-680 & 54.01 & 24.85 & 39.43 & 16.77 & 8.54 & 12.66 & 3.22 & 2.91 & 3.07 \\
\hline NDU-12-300 & 20.87 & 11.91 & 16.39 & 7.55 & 4.66 & 6.11 & 2.76 & 2.55 & 2.66 \\
\hline LBG-685 & 32.90 & 21.30 & 27.10 & 10.22 & 8.00 & 9.11 & 3.22 & 2.66 & 2.94 \\
\hline KU-12-14 & 31.77 & 22.93 & 27.35 & 8.88 & 6.89 & 7.89 & 3.58 & 3.33 & 3.45 \\
\hline LBG-645 & 47.32 & 27.37 & 37.35 & 13.33 & 8.77 & 11.05 & 3.55 & 3.12 & 3.34 \\
\hline KU-12-37 & 44.64 & 31.75 & 38.20 & 15.89 & 10.22 & 13.05 & 2.81 & 3.11 & 2.96 \\
\hline TBG-104 & 69.39 & 57.34 & 63.37 & 16.88 & 14.55 & 15.72 & 4.11 & 3.94 & 4.03 \\
\hline KU-12-13 & 32.28 & 23.81 & 28.05 & 10.77 & 8.22 & 9.50 & 3.00 & 2.90 & 2.95 \\
\hline LBG-752 & 40.41 & 26.88 & 33.65 & 12.55 & 9.00 & 10.78 & 3.22 & 2.99 & 3.10 \\
\hline LBG-20 & 31.40 & 22.16 & 26.78 & 10.11 & 8.33 & 9.22 & 3.11 & 2.66 & 2.88 \\
\hline \multirow[t]{2}{*}{ Mean } & 38.78 & 25.90 & & 12.02 & 8.63 & & 3.19 & 2.92 & \\
\hline & $\mathbf{T}$ & $\mathbf{G}$ & $\mathbf{T} \times \mathbf{G}$ & $\mathbf{T}$ & $\mathbf{G}$ & $\mathbf{T} \times \mathbf{G}$ & $\mathbf{T}$ & $\mathbf{G}$ & $\mathbf{T} \times \mathbf{G}$ \\
\hline $\mathrm{SE} \mathrm{m} \pm$ & 0.19 & 1.50 & 0.65 & 0.04 & 0.47 & 0.15 & 0.005 & 0.13 & 0.01 \\
\hline$C D(P=0.05)$ & 1.17 & 4.28 & 6.12 & 0.28 & 1.36 & 1.93 & 0.03 & 0.38 & NS \\
\hline
\end{tabular}

$\mathrm{M}_{0}$ : Irrigated (control), $\mathrm{M}_{1}$ : Moisture stress 
Table.2b Evaluation of blackgram genotypes for yield components under imposed moisture stress condition during rabi 2016-17

\begin{tabular}{|c|c|c|c|c|c|c|c|c|c|}
\hline & \multicolumn{3}{|c|}{ Number. of Pods per plant } & \multicolumn{3}{|c|}{ Number of clusters per plant } & \multicolumn{3}{|c|}{ Number of pods per cluster } \\
\hline Genotype & $\mathbf{M}_{0}$ & $\mathbf{M}_{1}$ & Mean & $\mathbf{M}_{0}$ & $\mathbf{M}_{1}$ & Mean & $\mathbf{M}_{0}$ & $\mathbf{M}_{1}$ & Mean \\
\hline KU-12-55 & 20.52 & 11.13 & 15.83 & 10.21 & 8.01 & 9.11 & 2.01 & 1.39 & 1.70 \\
\hline LBG-623 & 25.04 & 14.62 & 19.83 & 11.54 & 8.12 & 9.83 & 2.17 & 1.80 & 1.99 \\
\hline LBG-680 & 41.73 & 12.37 & 27.05 & 14.29 & 7.45 & 10.87 & 2.92 & 1.66 & 2.29 \\
\hline NDU-12-300 & 19.23 & 8.56 & 13.90 & 8.78 & 5.56 & 7.17 & 2.19 & 1.54 & 1.87 \\
\hline LBG-685 & 17.79 & 8.12 & 12.95 & 9.72 & 7.12 & 8.42 & 1.83 & 1.14 & 1.49 \\
\hline KU-12-14 & 32.64 & 14.26 & 23.45 & 10.88 & 5.55 & 8.22 & 3.00 & 2.57 & 2.79 \\
\hline LBG-645 & 37.94 & 15.94 & 26.94 & 13.22 & 7.89 & 10.56 & 2.87 & 2.02 & 2.45 \\
\hline KU-12-37 & 29.18 & 15.27 & 22.22 & 13.83 & 9.31 & 11.57 & 2.11 & 1.64 & 1.88 \\
\hline TBG-104 & 60.60 & 51.38 & 55.99 & 15.78 & 14.00 & 14.89 & 3.84 & 3.67 & 3.76 \\
\hline KU-12-13 & 36.73 & 22.49 & 29.61 & 14.29 & 12.78 & 13.54 & 2.57 & 1.76 & 2.17 \\
\hline LBG-752 & 31.49 & 16.26 & 23.88 & 11.05 & 7.97 & 9.51 & 2.85 & 2.04 & 2.45 \\
\hline LBG-20 & 28.49 & 14.42 & 21.45 & 10.59 & 7.21 & 8.90 & 2.69 & 2.00 & 2.35 \\
\hline \multirow[t]{2}{*}{ Mean } & 31.78 & 17.07 & & 12.02 & 8.41 & & 2.59 & 1.94 & \\
\hline & $\mathbf{T}$ & $\mathbf{G}$ & $\mathbf{T} \times \mathbf{G}$ & $\mathbf{T}$ & $\mathbf{G}$ & $\mathbf{T} \times \mathbf{G}$ & $\mathbf{T}$ & $\mathbf{G}$ & $\mathbf{T} \times \mathbf{G}$ \\
\hline $\mathrm{SE} \mathrm{m} \pm$ & 0.16 & 1.19 & 0.58 & 0.04 & 0.47 & 0.15 & 0.009 & 0.10 & 0.03 \\
\hline$C D(P=0.05)$ & 1.04 & 3.40 & 4.87 & 0.28 & 1.35 & 1.92 & 0.05 & 0.29 & N.S \\
\hline
\end{tabular}

$\mathrm{M}_{0}$ : Irrigated (control), $\mathrm{M}_{1}$ : Moisture stress 
Fig.1a Evaluation of blackgram genotypes for root length $(\mathrm{cm})$ under imposed moisture stress condition during rabi 2015-16 at 60 DAS

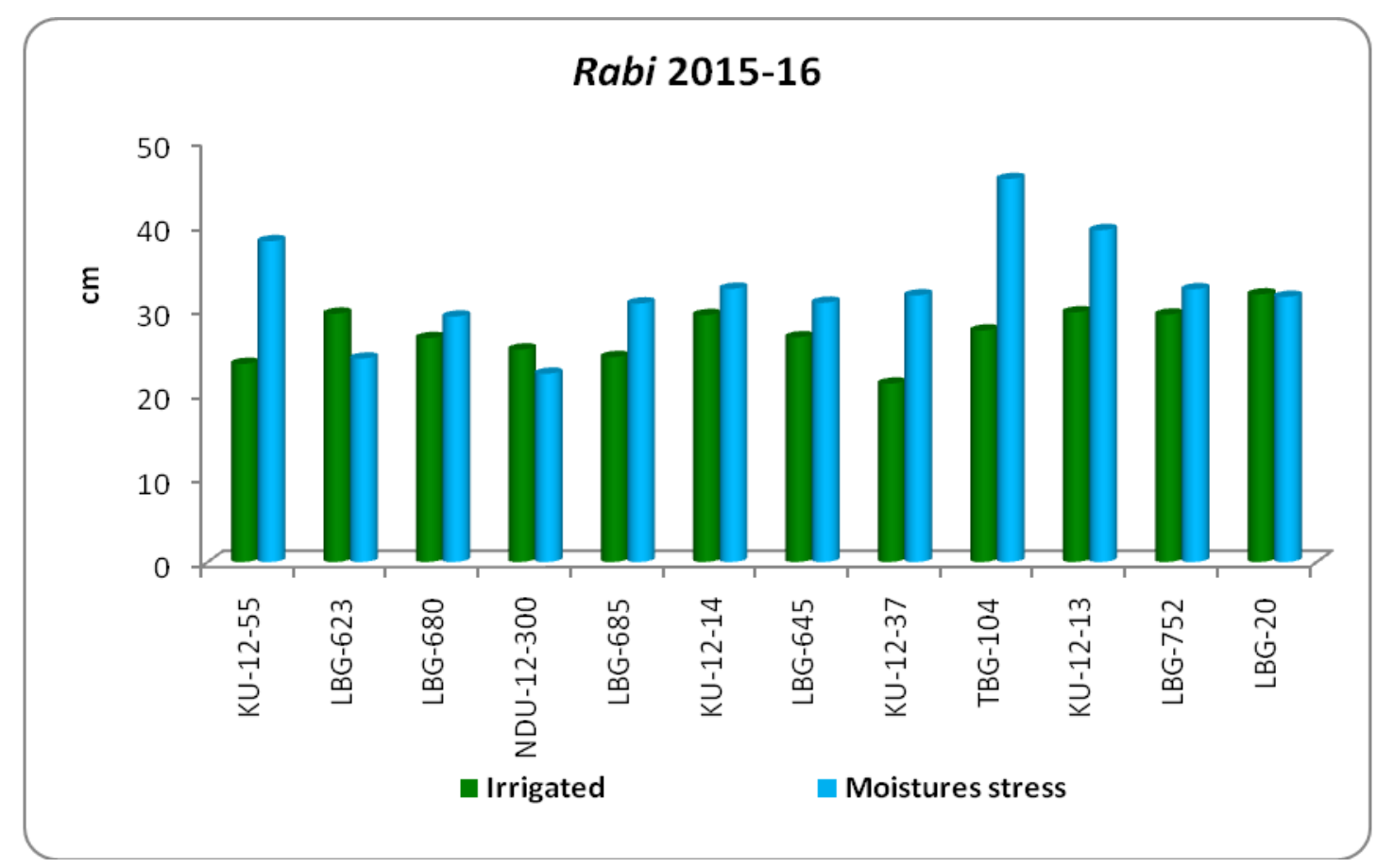

Fig.1b Evaluation of blackgram genotypes for root length $(\mathrm{cm})$ under imposed moisture stress condition during rabi 2016-17 at 60 DAS

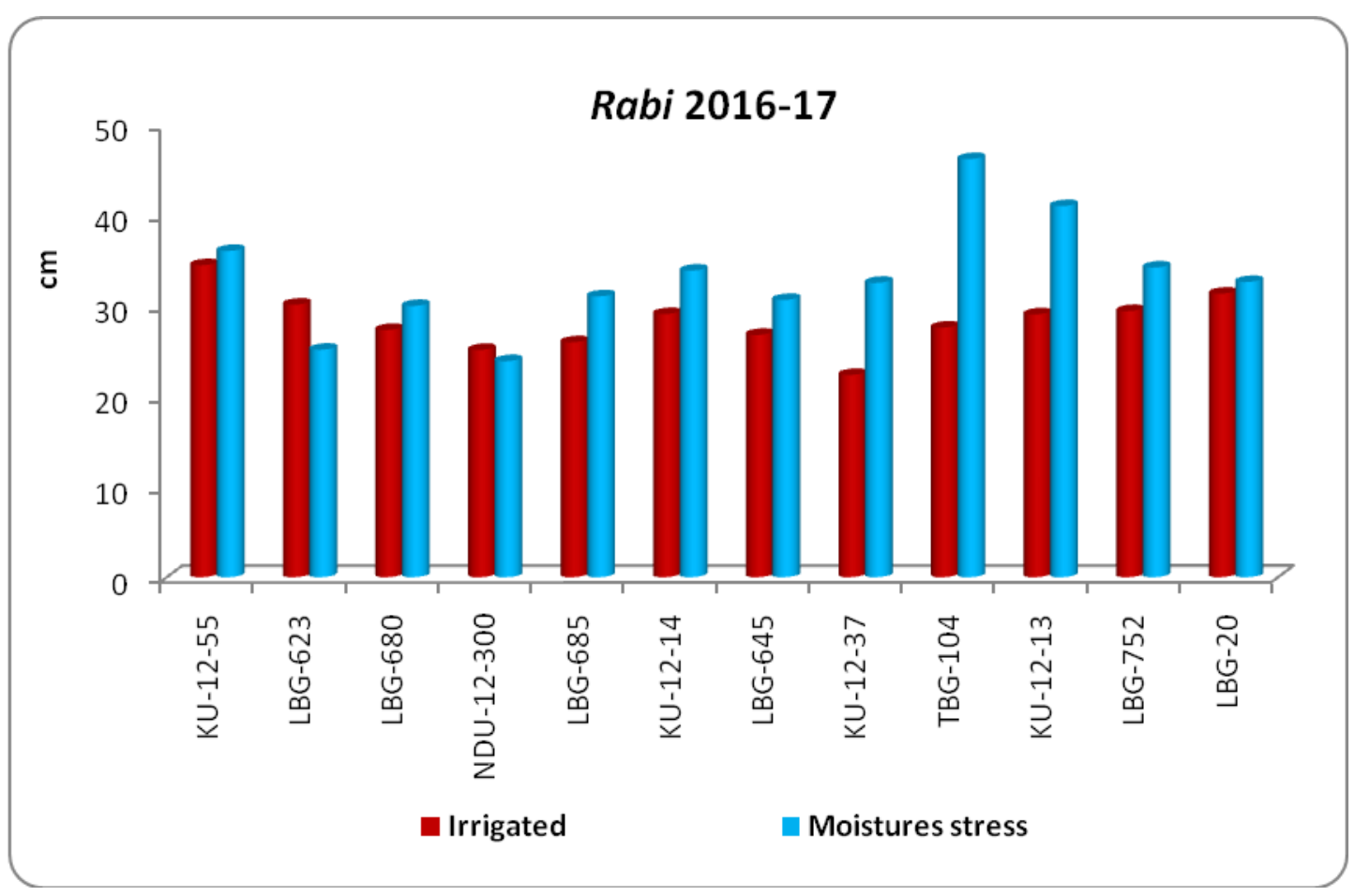


Fig.2a Evaluation of blackgram genotypes for root dry weight $\left(\right.$ g plant $^{-1}$ ) under imposed moisture stress condition during rabi 2015-16 at 60 DAS

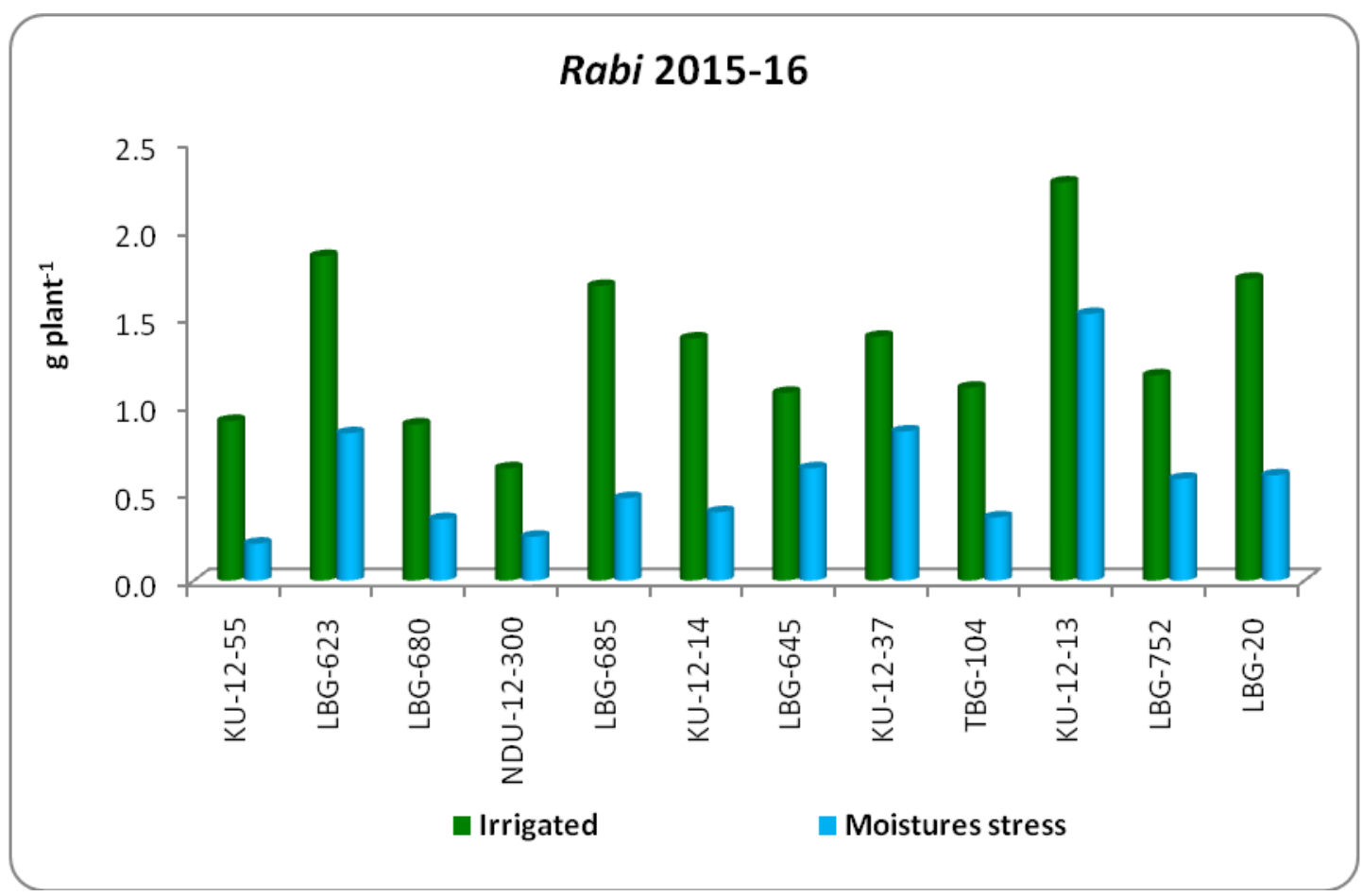

Fig.2b Evaluation of blackgram genotypes for root dry weight $\left(\mathrm{g}\right.$ palnt $\left.{ }^{-1}\right)$ under imposed moisture stress condition during rabi 2016-17 at 60 DAS

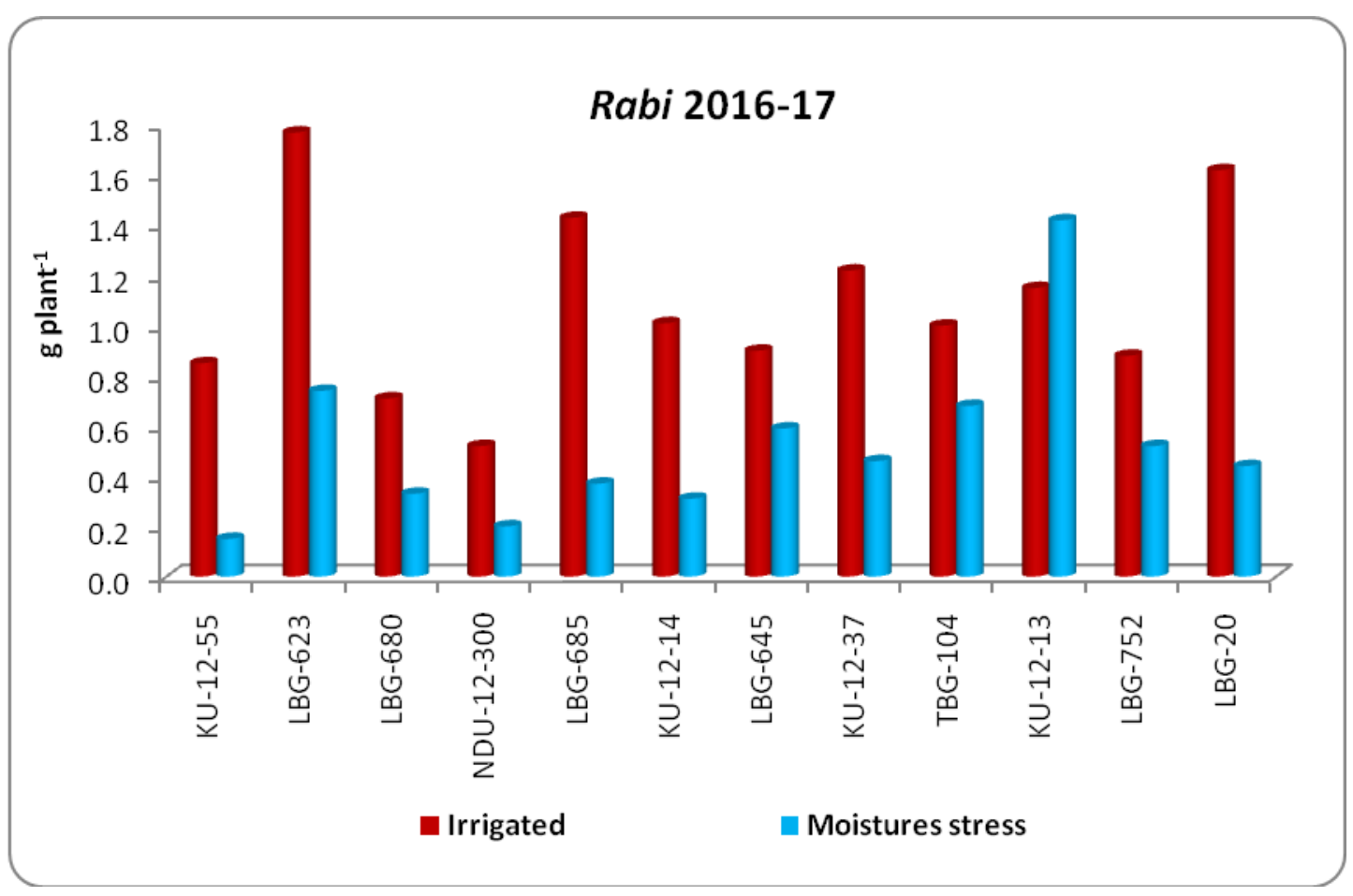


Plate.1 Effect of imposed moisture stress for water mining roots traits at 60 DAS during rabi 2015-16 and rabi 2016-17

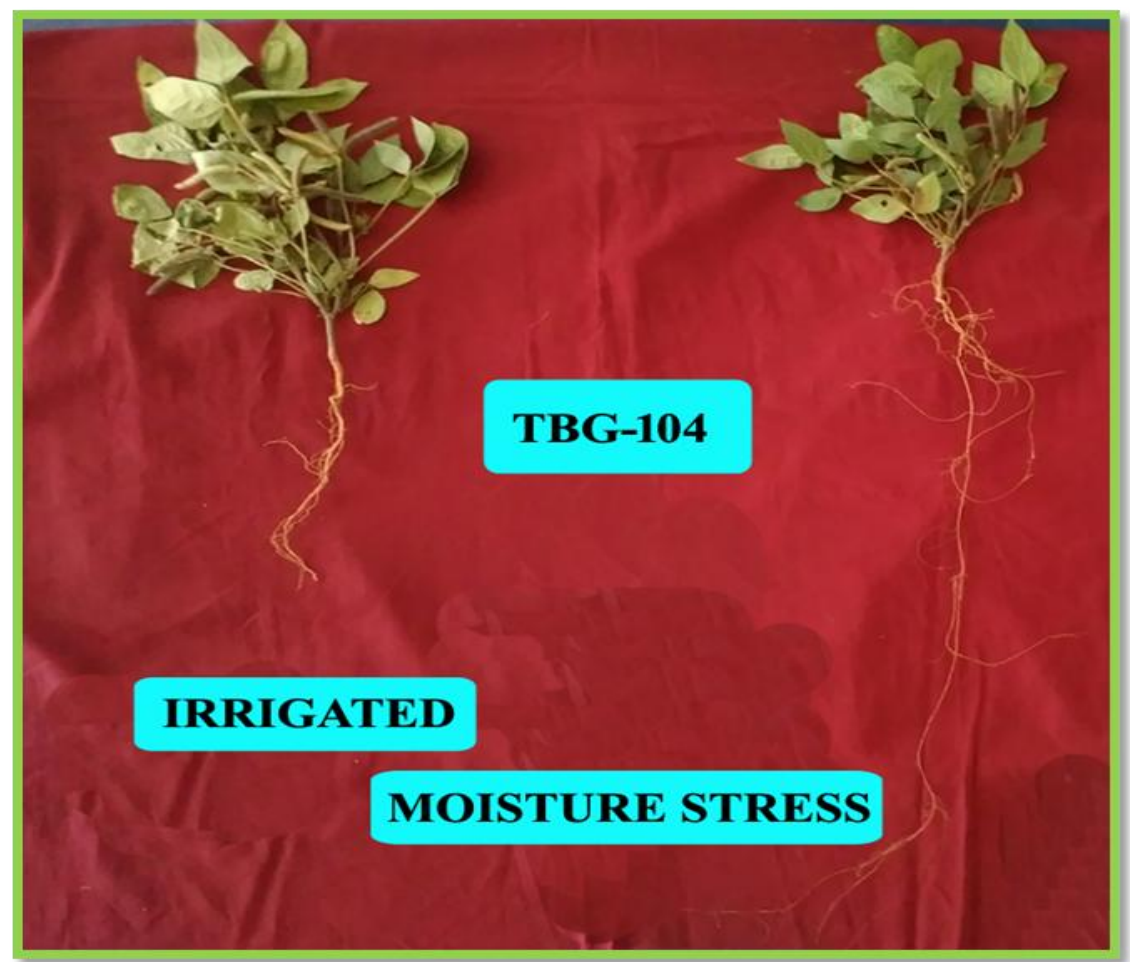

rabi 2015-16

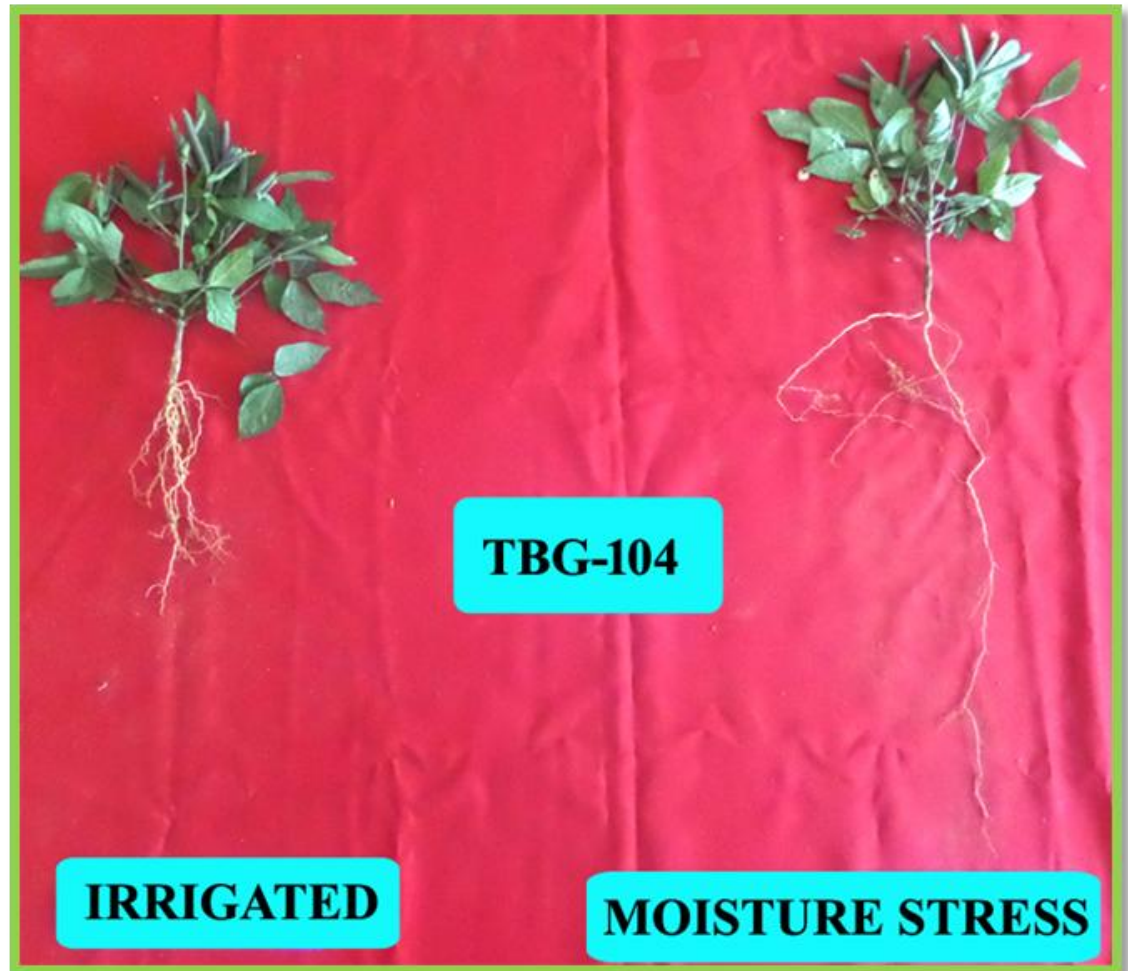

rabi 2016-17 
However, reduction in number of pods per cluster was 8.4 and 25.0 per cent during rabi 2015-16 and rabi 2016-17. Similar results were found in mungbean (Naresh et al., 2013). Among the genotypes, TBG-104 recorded highest mean number of pods per cluster (4.03 and 3.76) followed by LBG-680, and LBG-645 recorded moderate number of pods per cluster, whereas NDU-12-300 recorded lowest number of pods per cluster (Table 2a and 2B).

In conclusion, TBG-104, KU-12-13, KU-1237 recorded higher mean root length, however dry weight was decreased. Post harvest parameters viz., number pod per plant, number of cluster per plant, number of pods per cluster were significantly reduced due to moisture stress compared to control. TBG-104, KU-1213 and KU-12-37which maintained higher growth, physiological and drought tolerance attributes recorded higher yield. The genotype NDU-12-300, KU-12-14 and LBG 645 recorded lower yields under imposed moisture stress conditions as these genotypes recorded lower physiological attributes and drought susceptibility character.

\section{References}

Anitha, Y., Vanaja, M., Sunitha, V., Sowmya, P., Sathish, P and Vijay Kumar, G. 2015. Performance of blackgram genotypes under moisture deficit stress - Variability in physiological and yield contributing attributes. International Journal on Current Science 17: 82-89.

Baroowa, B and Gogoi, N. 2014. Biochemical changes in black gram and green gram genotypes after imposition of drought stress. Journal of Food Legumes. 27(4): 350-353

Behmann, J., Steinrücken, J., Plümer, L., 2014. Detection of early plant stress responses in hyperspectral images. ISPRS J. Photogramm. Remote Sens.
93, 98-111.

Biradar.S., Kaveri, Salimath, P.M and Ravi Kumar, R.L. 2007.Association of early vigour with drought tolerance in greengram (Vigna radiate (L.) Wilczek). Karnataka Journal of Agricultural Sciences. 20(3): 610-612.

DahanayakeNilanthi, Ranawake, A.L and Senadhipathy, D.D. 2014. Effects of Water Stress on the Growth and Reproduction of Blackgram (Vigna mungo L.). Tropical Agricultural Research \& Extension 17(1): 45-48.

Dhole, V. J. and Reddy, K. S. 2010. Gamma rays induced moisture stress tolerant long root mutant in mungbean (Vignaradiata L Wilczek). Electronic Journal of Plant Breeding, 1(5):12991305.

Garces-Restrepo, C., Vermillion, D., Munoz, G. 2007. Irrigation management transfer. Worldwide efforts and results. FAO, Rome. 62.

Hirich, A., Fatnassi, H., Ragab, R., ChoukrAllah, R., 2016.Prediction of climate change impact on corn grown in the south of morocco using the saltmed model. Irrig. and Drain. 65, 9-18.

Lei, Y., Zhang, H., Chen, F., Zhang, L., 2016. How rural land use management facilitates drought risk adaptation in a changing climate-A case study in aridnorthern China. Sci. Total Environ. 550, 192-199.

LutforRahman, S.M., Eiji Nawata., Testuosakuratani and Mesbah Uddin, A.S.M. 2000. Ecological adaptation of chickpea (Cicer areitinum L.) to water stress. Legume Research. 23: 141-145.

Naresh, R.K., Purushottam, R.K., Singh, S.P., Ashish Dwivedi and Vineet Kumar. 2013. Effects of water stress on physiological processes and yield attributes of different mungbean (L.) varieties. African Journal of Biochemistry Research. 7(5): 55-62. 
Onuh M. O and Donald, K. M. 2009.Effects of Water Stress on the Rooting, Nodulation Potentials and Growth of Cowpea (Vigna unguiculata (L) Walp). Science World Journal. Vol 4 (3):31-34.

Pandey, S., Ror, S., Chakraborty, D., 2014. Analysis of biochemical responses in Vignamungo varieties subjected to drought stress and possible amelioration. International Journal of Scientific Research in Agricultural Sciences. 1(1), 6-15.

Pandiyan, M., Senthil, N., Balaji, T., Veeramani, P., Savitha, B. K., Sendhilvel, V and Gopilkrishnan, A. 2017.Studies on Performance of Drought tolerant Genotypes under Drought and normal conditions through Morpho, Physio and Biochemical attributes of Blackgram (Vigna mungo L.) and Greengram (Vigna radiata L.). International Journal of Advanced. Research. 5(2): 489-496.

Parameshwarappa, S.G., Salimath, P.M., Upadhyaya, H.D., Patil, S.S., Kajjidoni, S.T., Patil, B. C and Narayana, Y. D. 2012. Variation in root characters of selected drought tolerant accessions of chickpea (Cicer arietinum L.) grown under terminal drought. Karnataka
Journal of Agricultural Science. 25(3): 389-391.

Saravanakumar, D., Harish, S., Loganathan, M., Vivekananthan, R., Rajendran, L., Raguchander, T., Samiyappan, R., 2007. Rhizobacterial bioformulation for the effective management of Macrophomina root rot in mungbean. Archives of Phytopathology and Plant Protection. 40(5), 323-337.

Tej Pal Singh.,Deshmukh, P.S and Kushwaha, S. R.2003. influence of high temperature and moisture content on growth development and yield of chickpea genotypes. II International Congress on Plant Physiology. New Delhi. PP: 235.

Uddin, S., Parvin, S and Awal, M. A. 2013.Morpho-Physiological aspects of Mungbean (Vigna radiata L.) in response to water stress. International Journal of Agricultural Science and Research. 3(2): 137-148.

Venkateswarlu, O. 2005. Genetic analysis of physiological and yield attributes related to drought tolerance in groundnut (Arachis hypogaea L.). Ph.D. Thesis, Acharya N.G. Ranga Agricultural University, Hyderabad.

\section{How to cite this article:}

Yohan, Y., P. Sudhakar, V. Umamahesh, D. Mohan Reddy and Sumathi, V. 2018. Influence of Moisture Stress on Root Traits and Yield Components of Mungbean Genotypes. Int.J.Curr.Microbiol.App.Sci. 7(12): 2867-2877. doi: https://doi.org/10.20546/ijcmas.2018.712.326 